loging, first in the former Serials and Electronic Resources Unit, where she handled serials and video catalogings, and, finally, since October 1999 , in the MARC Unit, where she has served as the serials support cataloger for all non-Slavic, nonHebrew serial titles.

Charlotte Derksen, head of the Branner Library, has retired from Stanford University after 23 years of service. Derksen has been very active and played a leadership role in professional organizations for earth sciences librarians, including the Geoscience Information Society, American Geological Institute, GeoRef, Geological Society of America, Cartographic Users Advisory Council, ALA-Map and Geography Round Table, and the Research Libraries Group. She has published over 20 articles on collection development and public service issues and has won the best paper from the Geoscience Information Society for the past two years. By request from the Geological Society of America, she developed a Web page called "Selected Web Sites for Geoscientists." Derksen compiled information for the monograph "Union List of Geologic Field Trip Guidebooks," 5 th ed. (1989) - a core title that is purchased by virtually all earth sciences libraries.

John Jax, after 44 years (32 as director), has retired from the library at the University of Wisconsin-Stout. Jax first joined the library as an assistant librarian in 1959. In 1971, he was named head librarian and assistant dean for the school of learning resources. During his tenure, the campus library has grown from a collection of over 75,000 volumes to over 225,000 . It was also

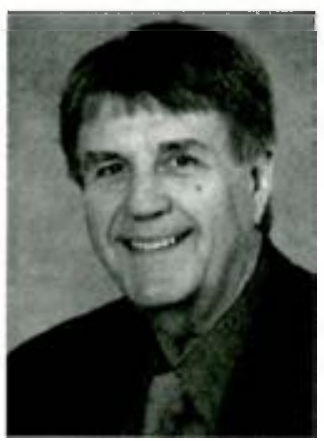

John Jax during his tenure that, following the construction of a new $\$ 6.7$ million facility, the Stout library became the first in the University of Wisconsin System to have an integrated automated library system. In 1983, the new facility was named the Library of the Year by the Wisconsin Library Association. Five years later, the Library Learning Center was honored as one of 49 Centers of Excellence in the University of Wisconsin System. Jax has served as president of the Wisconsin Library Association, chair of the Consortium of Hospitality Research Information Ser- vices, and chair of the Council of Wisconsin Libraries, and was named Librarian of the Year by the Wisconsin Library Association in 1986. From 1979 to 1980, Jax served as a national delegate in Washington, D.C. for the White House Conference on Library and Information Services.

Anne Rees retired from the Old Dominion University (ODU) Libraries in December 2003. Rees joined ODU in 1978 as a science reference librarian.

Bonnie H. Schuster, professor of library services and systems librarian at the University of Montana-Missoula (UM), retired in December 2003 , after a 35-year career in academic librarianship. Schuster began her professional career as a reference librarian at Iowa State University in 1968 , and assumed a similar position at Washington State University in 1973. In 1979, she moved to Missoula to become monographic acquisitions librarian at the UM's Maureen and Mike Mansfield Library. In 1990, she became UM's interim head of technical services and, in 1991, she was named systems librarian. During her tenure at UM, Schuster oversaw the implementation of two online library management systems and she brought many honors to campus, including being selected in 1985 to assist the Fred Meyer Charitable Trust with its Library and Information Resources Program to improve access to information resources in the Pacific Northwest. Schuster has been active in many professional library associations, including serving multiple terms on the boards of the Montana Library Association, the Pacific Northwest Library Association, the Mountain Plains Library Association, and the user group boards for each library management system.

\section{Advertiser index}

$\begin{array}{lr}\text { ACM } & \text { Cover } 3 \\ \text { Annual Reviews } & 99 \\ \text { Assoc. of Research Libraries } & 98 \\ \text { ACRL/Univ. of Arizona } & 97 \\ \text { Chemical Abstracts Services } & \text { Cover } 2 \\ \text { CHOICE } & 62 \\ \text { EBSCO } & \text { Cover } 4 \\ \text { John Wiley \& Sons Inc. } & 77 \\ \text { Oxford University Press } & 91,104 \\ \text { Paratext } & 69 \\ \text { ScienceDirect } & 59\end{array}$

